"Impact of demographic characteristics of personnel on the quality of employee relationships: The case of Poland"

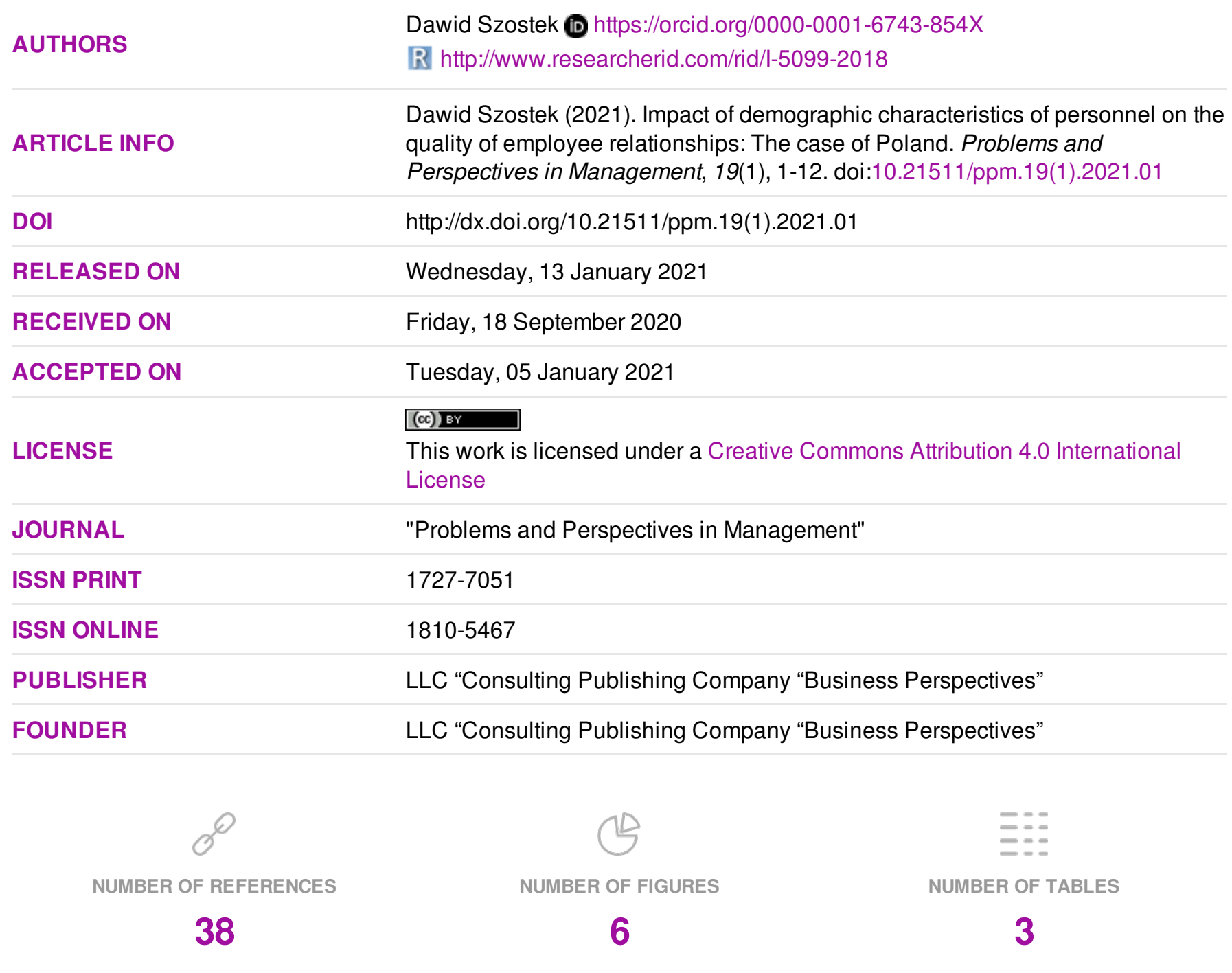

(C) The author(s) 2021. This publication is an open access article. 


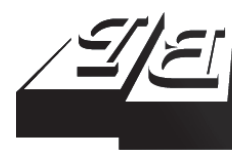

BUSINESS PERSPECTIVES

(O)

LLC "CPC "Business Perspectives" Hryhorii Skovoroda lane, 10, Sumy, 40022, Ukraine www.businessperspectives.org

Received on: $18^{\text {th }}$ of September, 2020 Accepted on: $5^{\text {th }}$ of January, 2021 Published on: $13^{\text {th }}$ of January, 2021

(C) Dawid Szostek, 2021

Dawid Szostek, Ph.D., Associate Professor, Department of Organizational Behaviour and Marketing, Faculty of Economic Sciences and Management, Nicolaus Copernicus University in Torun, Poland.

\section{IMPACT OF DEMOGRAPHIC CHARACTERISTICS OF PERSONNEL ON THE QUALITY OF EMPLOYEE RELATIONSHIPS: THE CASE OF POLAND}

\begin{abstract}
This research paper fills a significant gap in the literature in the field of the influence of demographic characteristics of employees on the quality of interpersonal relationships at work (QR). There are no comprehensive research results concerning this problem. The research objective is to describe how selected characteristics of employees (sex, age, education, type of job, and length of service) influence QR. This goal was achieved through the use of survey methods (online, direct and auditory) conducted in 2018 and 2019 on the sample of 1,336 active employees in Poland. The data was analyzed using IBM SPSS Statistics application. The findings prove that the quality of interpersonal relationships at work is differentiated by sex (men tend to rate the quality of relationships higher as compared to women), age (respondents belonging to younger groups tend to rate the quality of relationships higher as compared to older respondents), education (respondents with higher education tend to rate the quality of relationships higher as compared to less educated respondents), and type of job (managers tend to rate the quality of relationships higher as compared to the blue-collar workers). It was not possible to determine explicit trends in assessing the quality of relationships depending on the term of work. According to obtained results, special attention should be paid to the following categories of staff: women, older, less educated and blue-collar employees.
\end{abstract}

Keywords

employees, personnel management, quality of relationships, interpersonal relationships, comparison, Poland

JEL Classification M12, D23, J24

\section{INTRODUCTION}

The quality of interpersonal relationships at work $(\mathrm{QR})$ is very important not only for functioning of employees themselves, but also their surroundings (e.g. members of their families) and an organization itself (Jędrzejczak-Gas \&Wyrwa, 2020). This construct has an extraordinarily biased character and depends on numerous determinants, including individual and situational (divided into organizational and non-organization). One of the determinants most frequently considered in the literature on personnel management and QR are sex, age, education, length of service and type of job. The first three are individual and the last two are organizational determinants (see e.g. Tschan et al., 2004; Bowler \& Brass, 2006; LePine et al., 2012; Robak, 2017; Vasilyeva et al., 2018). However, there is no comprehensive research on the influence of the variables on the quality of interpersonal relationships between employees. What is more, the influence of the variables is often understood intuitively as a recognized, but not confirmed or barely examined empirically paradigm. For instance, as Heaphy indicates (2009), women engage in relationships more emotionally as compared to men, and they are less direct in interaction as compared 
to men. On the other hand, Gersick et al. (2000) notice that women are also less integrated with their direct environment in an organization. A considerable hindrance in analyzing the influence of the above-mentioned variables on $\mathrm{QR}$ is also the fact that the variables should be considered on the basis of a comparison both in research and practice of an organization (O’Reilly III et al., 1989).

\section{LITERATURE REVIEW}

Each human activity is grounded in interpersonal relationships (Mainela, 2007). An organization is the best place to incubate such relationships because employees are close to each other and interact a lot (Jehn et al., 2014). The relationship at work combines two dimensions, namely task-related and interpersonal (LePine et al., 2012). The first one predominates and focuses on proper performance of tasks (LePine et al., 2012). Thus, literature on work relationships focuses on the task-related component. The interpersonal component focuses on interpersonal relationships between employees. The deeper is this relationship, the closer become the parties (Jehn et al., 2014). The interpersonal component means that this relationship can take a form of verbal (e.g., conversation), para-verbal (e.g., exclamation of surprise), non-verbal (e.g., a smile) and physical (e.g., touching) communication (Laschober et al., 2012).

Interpersonal relationships have a dichotomous character and, thus, they can be good (positive, of high quality) or bad (negative, of low quality). They rarely assumed extreme forms, but more often constitute a certain resultant of good-bad continuum (thus, relationships can be graded). Due to dominant interest in the literature in the positive character of the relationships, it seems much easier to qualify relationships as good than deem the same bad (Szostek \& Glińska-Neweś, 2017; Pisar \& Bilkova, 2019).

Quality interpersonal relations at work could be built of different levels and described on different theoretical backgrounds such as: human capital management or positive organizational behavior (Sułkowski et al., 2020; Przytuła et al., 2014; Lenart-Gansiniec \& Sułkowski, 2020).

The literature on the subject does not use a uniform definition of interpersonal relationships at work (see Table 1). What is more, deliberations of numerous authors are often explicitly general in nature (Glińska-Neweś, 2017). However, it is possible to indicate certain symptoms of good or bad relationships. The good symptoms are associated, among others, with greater honesty, trust, closeness, satisfaction and involvement, more often include emotions (not only positive, but also negative), interactions and communications among employees, are characterized by helping behaviors towards co-workers, they last long and often extend outside the sphere of work and are even identified with friendship. Low quality relationships are full of suspiciousness and do not give any satisfaction, they include little emotion or are dominated by negative emotions, interactions are short-term and limited to necessary minimum, they are characterized by limited communication and are devoid of private sphere and more often dominated by counterproductive work behaviors towards others (see e.g. Carmeli, 2009; Carmeli et al., 2009; Carmeli \& Gittell, 2009; Kot-Radojewska \& Timenko, 2018; Szostek, 2019; Polyanska et al., 2019). The indicated symptoms of the quality of relationships should be approached with high cautiousness, because their absence or presence does not have to prove the fact that a relationship is positive or negative. The only certain thing is that the quality of interpersonal relationships at work is a totally subjective construct (and thus depends on employees' individual assessment, which symptoms dominate in the relationship and to what extent, and whether the expectations for the relationship have been met (Atrek et al., 2014; Belas et al., 2015).

The quality of interpersonal relationships at work is a barely examined and described issue, especially in the context of Polish cultural conditions. This may result, among others, from deficiency of instruments (scales) for measuring of the quality. This can be derived from the lack of a comprehensive list of variables identified for the QR measurement.

A scale adapted to Polish conditions was proposed by Szostek (2019), who identified four categories of variables for measuring the quality of relation- 
Table 1. Selected definitions and approaches to interpersonal relationships at work

\begin{tabular}{|c|c|}
\hline Source & Definition \\
\hline Gabarro (1990, p. 8) & Interpersonal relationship that is task-based, nontrivial, and of continuing duration. \\
\hline Storbacka et al. (1994) & $\begin{array}{l}\text { QR is identified with its strength of links between the parties that lead to satisfaction and } \\
\text { commitment. }\end{array}$ \\
\hline Hinde $(1997$, p. 37) & A series of interactions between two people, involving interchanges over an extended period of time. \\
\hline Sherony and Green (2002) & It is the level of mutual respect, trust and sense of duty between employees. \\
\hline McGinn and History (2009, p. 265) & $\begin{array}{l}\text { Quality of relationship entails a pervasive, intentional, and constructive focus on mutual support and } \\
\text { on members as individuals. }\end{array}$ \\
\hline McCauley $(2012$, p. 9) & $\begin{array}{l}\text { Sequence of interactions between two people that involves some degree of mutuality, in that the } \\
\text { behavior of one member takes some account of the behavior of the other. } \\
\text { The evaluation of the co-workers' actions, their feelings and attitudes, and the relationship's results. }\end{array}$ \\
\hline Tepper and Almeda (2012) & The evaluation of how far a relationship is based on reciprocity. \\
\hline Atrek et al. (2014) & The degree to which a relationship meets the co-workers' expectations, needs and aspirations. \\
\hline
\end{tabular}

ships at work, such as: 1) organizational atmosphere, 2) interpersonal bonds, 3) methods of building of interpersonal relationships, and 4) distance resulting from management style. Moreover, the author pointed out two dimensions of interpersonal relationships at work, i.e.: 1) determinants vs. effects of QR (some of the variables are both determinants and effects, e.g. time spend together), 2) organizational (activities undertaken by an organization, e.g. corporate events) vs. individual manifestations (activities undertaken by an employee, e.g. helping co-workers by a move).

The gaps in the literature as identified and shown above made it possible to set the research objective, which is to describe how selected characteristics of employees (sex, age, education, type of job, and length of service) influence the quality of interpersonal relationships at work.

\section{DATA AND METHODOLOGY}

The study was conducted in 2018 and 2019 using survey methods (online, direct and auditory). The respondents were Polish employees, and invitations for participation in the study were sent to:

- nearly 2.5 thousand commune offices in Poland;

- 200 enterprises mentioned in the ranking list of Wprost weekly ${ }^{1}$ (200 largest enterprises in 2017);
26 enterprises from the Kujawsko-Pomorskie province (including six selected on an arbitrary basis and 20 selected as based on a ranking list of 500 largest Polish enterprises as published in Rzeczpospolita journal for 2016) ${ }^{2}$; and

- nearly 3.2 thousand students of the Faculty of Economic Sciences and Management of Nicolaus Copernicus University in Torun.

The quality of relationships was examined using the QIRT-S scale (Quality of Interpersonal Relationships in the Team Scale) proposed by Szostek (2019). The scale includes 58 items, and the respondents select one of the following options: strongly disagree; somewhat disagree; hard to say; somewhat agree; strongly agree (see Appendix). The statements have a positive meaning and are divided into the four above-mentioned categories (organizational atmosphere, interpersonal bonds, methods of building of interpersonal relationships, distance resulting from management style) and two dimensions, i.e. determinants vs. effects of the quality of relationships and an organizational vs. individual perspective.

In total, 1,336 correctly completed questionnaires were collected and analyzed using the IBM SPSS Statistic application. The empirical material was characterized by high validity (Cronbach Alpha coefficient amounted to 0.965 with an average of 3.615 and variance of 0.036 ) (Vveinhardt \& Gulbovaite, 2018; Lušňáková et al., 2019). Table 2 includes the characteristics of the respondents.

1 Wprost, Ranking of 200 Largest Polish Companies in 2017, https://rankingi.wprost.pl/200-najwiekszych-polskich-firm\#pelna-lista (10.09.2017).

2 Rzeczpospolita, The List of 500 - Edition 2016, https://sklep.rp.pl/produkt/lista_500_edycja_2015.php (24.02.2018). 
Table 2. Demographic characteristics of the sample

\begin{tabular}{|c|c|c|c|c|c|}
\hline \multirow{3}{*}{ Gender } & $F$ & $57.6 \%$ (770 persons) & \multirow{4}{*}{$\begin{array}{l}\text { Type of } \\
\text { position }\end{array}$} & Office/clerical & $49.9 \%$ (666 persons) \\
\hline & M & $40.6 \%$ (542 persons) & & Management & $27.6 \%$ (369 persons) \\
\hline & Unspecified & $1.8 \%$ (24 persons) & & Blue collar & 20.5\% (274 persons) \\
\hline \multirow{5}{*}{ Age } & Up to 35 years & $33.2 \%$ (444 persons) & & Unspecified & $2.0 \%$ (27 persons) \\
\hline & Up to 55 years & $46.6 \%$ (623 persons) & \multirow{3}{*}{$\begin{array}{l}\text { Region of } \\
\text { Poland }\end{array}$} & Kujawsko-pomorskie & $19.4 \%$ (259 persons) \\
\hline & Up to 75 years & $14.9 \%$ (199 persons) & & Śląskie & $9.7 \%$ (129 persons) \\
\hline & Unspecified & $5.3 \%$ (70 persons) & & Małopolskie & $7.1 \%$ (95 persons) \\
\hline & \multicolumn{2}{|c|}{$\begin{array}{l}\mathrm{AV}=40.3 \text { years; } \mathrm{MIN}=18 \text { years; } \mathrm{MAX}=67 \text { years; } \\
\mathrm{SD}=11.8 \text { years }\end{array}$} & & Podlaskie & $6.0 \%$ (80 persons) \\
\hline \multirow{6}{*}{ Education } & Higher & $56,7 \%$ (757 persons) & & Warmińsko-mazurskie & $6.0 \%$ (80 persons) \\
\hline & Secondary & $22.1 \%$ (295 persons) & & Mazowieckie & $5.9 \%$ (79 persons) \\
\hline & Vocational & $19.2 \%$ (256 persons) & & Świętokrzyskie & $5.9 \%$ (79 persons) \\
\hline & Basic & $0.3 \%$ (4 persons) & & Pomorskie & $5.8 \%$ (77 persons) \\
\hline & None & $0.3 \%$ (4 persons) & & Wielkopolskie & $5.3 \%$ (71 persons) \\
\hline & Unspecified & $1.4 \%$ (20 persons) & & Lubuskie & $4.8 \%$ (64 persons) \\
\hline \multirow{8}{*}{$\begin{array}{l}\text { Length of } \\
\text { service }\end{array}$} & Up to 1 year & $6.1 \%$ (82 persons) & & Łódzkie & $4.6 \%$ (62 persons) \\
\hline & Up to 5 years & $37.4 \%$ (499 persons) & & Podkarpackie & $4.5 \%$ (60 persons) \\
\hline & Up to 10 years & $13.8 \%$ (185 persons) & & Lubelskie & $4.2 \%$ (56 persons) \\
\hline & Up to 15 years & $14.1 \%$ (188 persons) & & Dolnośląskie & $4.0 \%$ (53 persons) \\
\hline & Up to 20 years & $8.6 \%$ (115 persons) & & Opolskie & $3.4 \%$ ( 45 persons) \\
\hline & Above 20 years & $12.0 \%$ (160 persons) & & Zachodnio-pomorskie & $3.1 \%$ (42 persons) \\
\hline & Unspecified & $8.0 \%$ (107 persons) & & & \\
\hline & \multicolumn{2}{|c|}{$\begin{array}{l}A V=9.7 \text { years; } M I N=1 \text { month; } M A X=48 \text { years; } \\
S D=9.9 \text { years }\end{array}$} & & & \\
\hline \multirow{3}{*}{ Sector } & Private & $50.8 \%$ (679 persons) & & & \\
\hline & Public & $48.9 \%$ (653 persons) & & & \\
\hline & Unspecified & $0.3 \%$ (4 persons) & & & \\
\hline
\end{tabular}

\section{RESULTS}

\section{AND DISCUSSION}

The analysis of data indicates that the respondents tended to assess the quality of interpersonal relationships in their place of work really high (18.3\% of the total statements for "strongly disagree" and "somewhat disagree", and $63.3 \%$ for "strongly agree" and "somewhat agree") (see Figure 1). Further, the analysis covered the development of the quality depending on selected demographic variables characterizing the respondents.

\subsection{The quality of relationships vs. a respondent's gender}

From the analysis of the data presented in Figure 2 , it can be seen that the quality of relationships at work is assessed as slightly higher by men as compared to women (men often tended to assess the

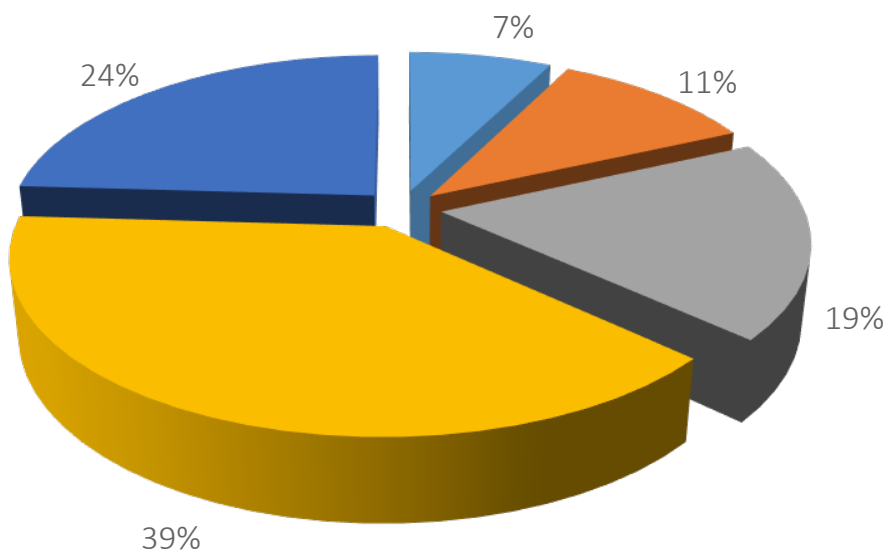

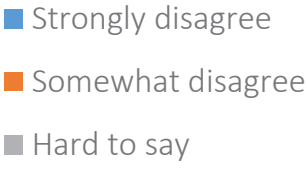

Somewhat agree

Dtrongly egree

Figure 1. Assessment of the quality of interpersonal relationships at work 


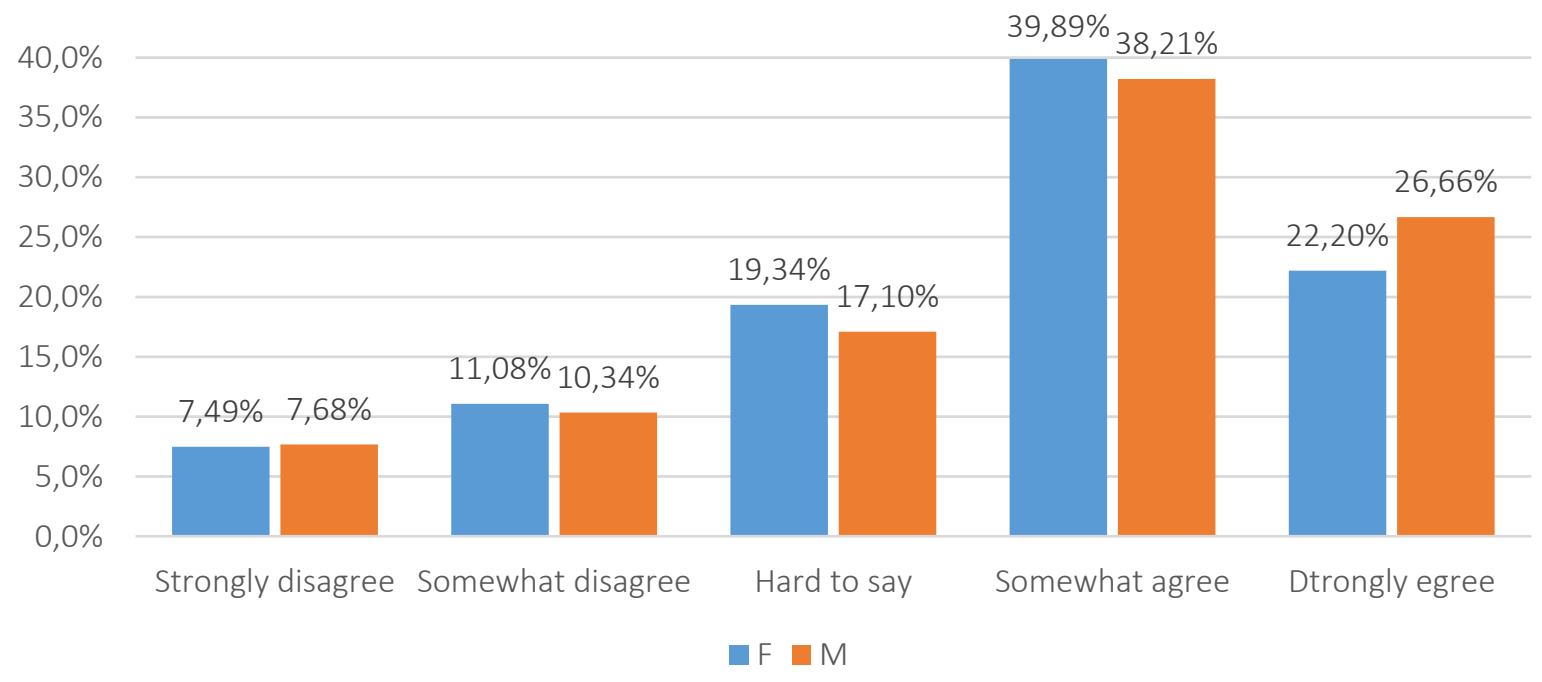

Figure 2. The quality of interpersonal relationships at work vs. a respondent's sex

relationships as positive and less frequently as negative and neutral).

\subsection{The quality of relationships vs. a respondent's age}

The youngest group of respondents (up to 35 years) was characterized by the highest quality of interpersonal relationships at work as compared to the remaining two age groups (up to 55 and 75 years). This is manifested in the lowest share of negative and neutral answers provided and highest share of positive answers in the group of respondents. On the other hand, the oldest group of respondents was characterized by the lowest quality of relationships (see Figure 3).

\subsection{The quality of relationships vs. a respondent's education}

The respondents' education also differentiated their assessments of the quality of interpersonal relationships at work. The higher the education, the more positive assessments. On the other hand, the group of respondents with the lowest education tended to assess the quality more negatively. This is evidenced by both the share of negative and neutral answers provided, as well as positive an-

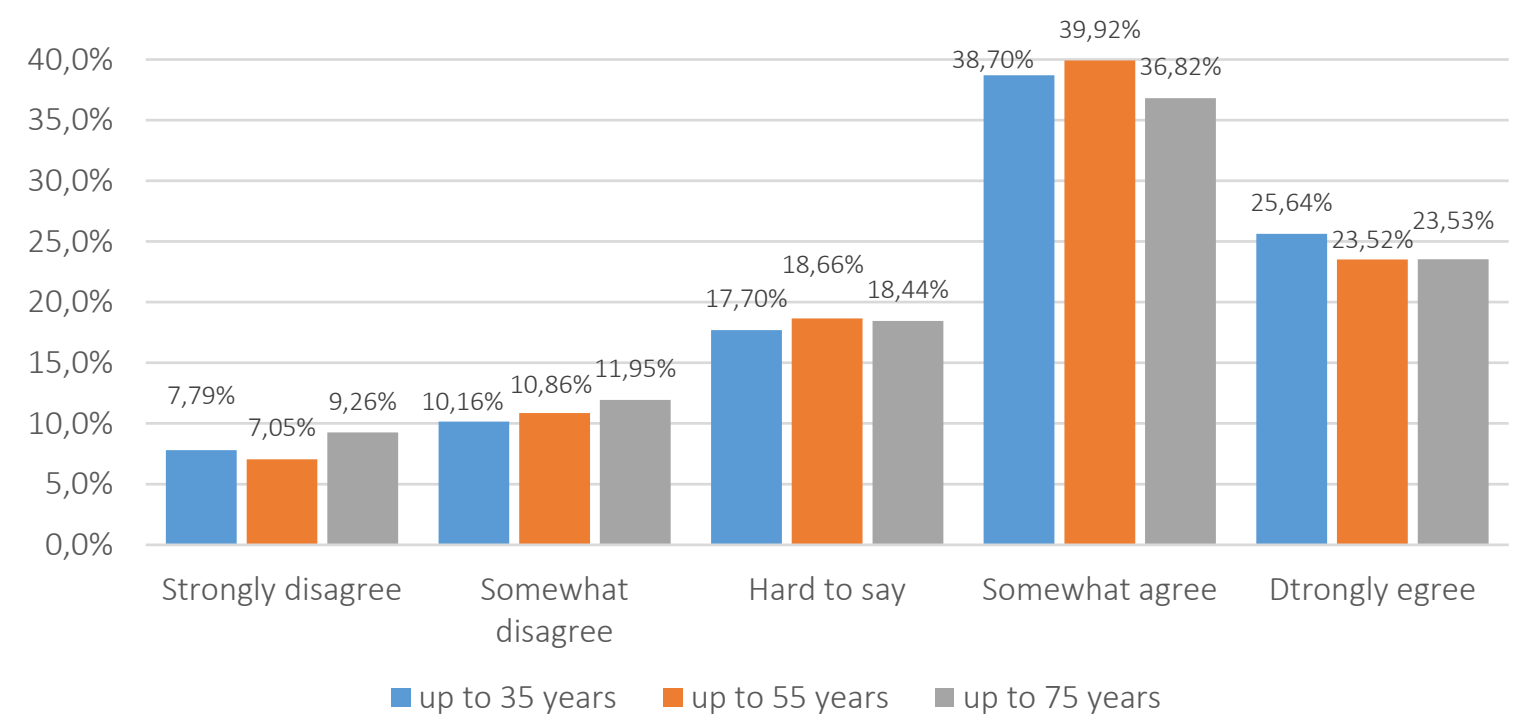

Figure 3. The quality of interpersonal relationships at work vs. a respondent's age 


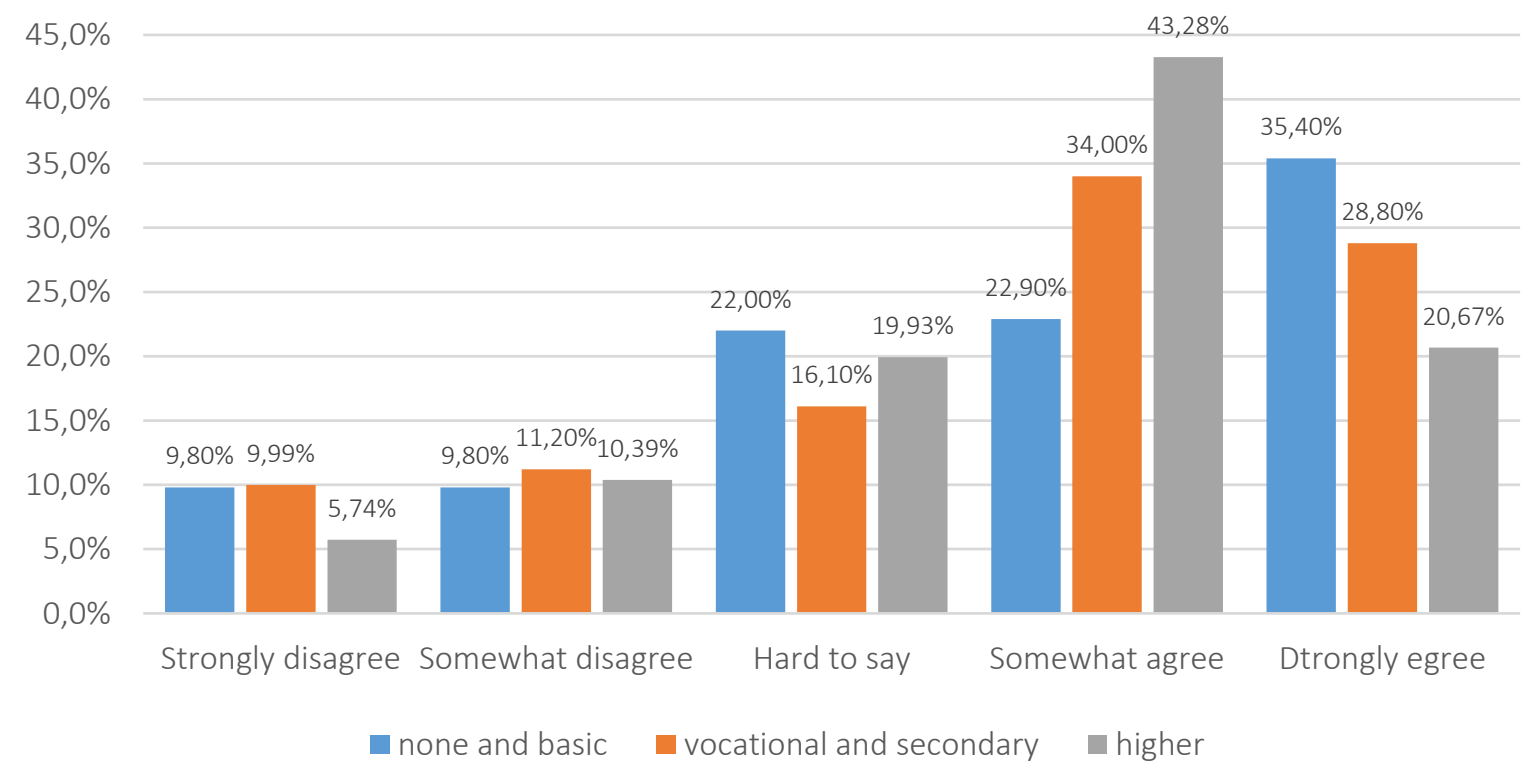

Figure 4. The quality of interpersonal relationships at work vs. a respondent's education

swers in the above-mentioned groups of respond- itive answers). On the other hand, workers holdents (see Figure 4$)^{3}$.

\subsection{The quality of relationships vs. a respondent's type of job}

Respondents holding executive posts tended to assess the quality of relationships at work the highest (this is manifested by the lowest share of negative ing physical positions of those connected with physical work assessed the quality as lowest (see Figure 5).

\subsection{The quality of relationships vs. a respondent's length of service} and neutral answers and the highest share of pos- lected due to their length of service at a given place

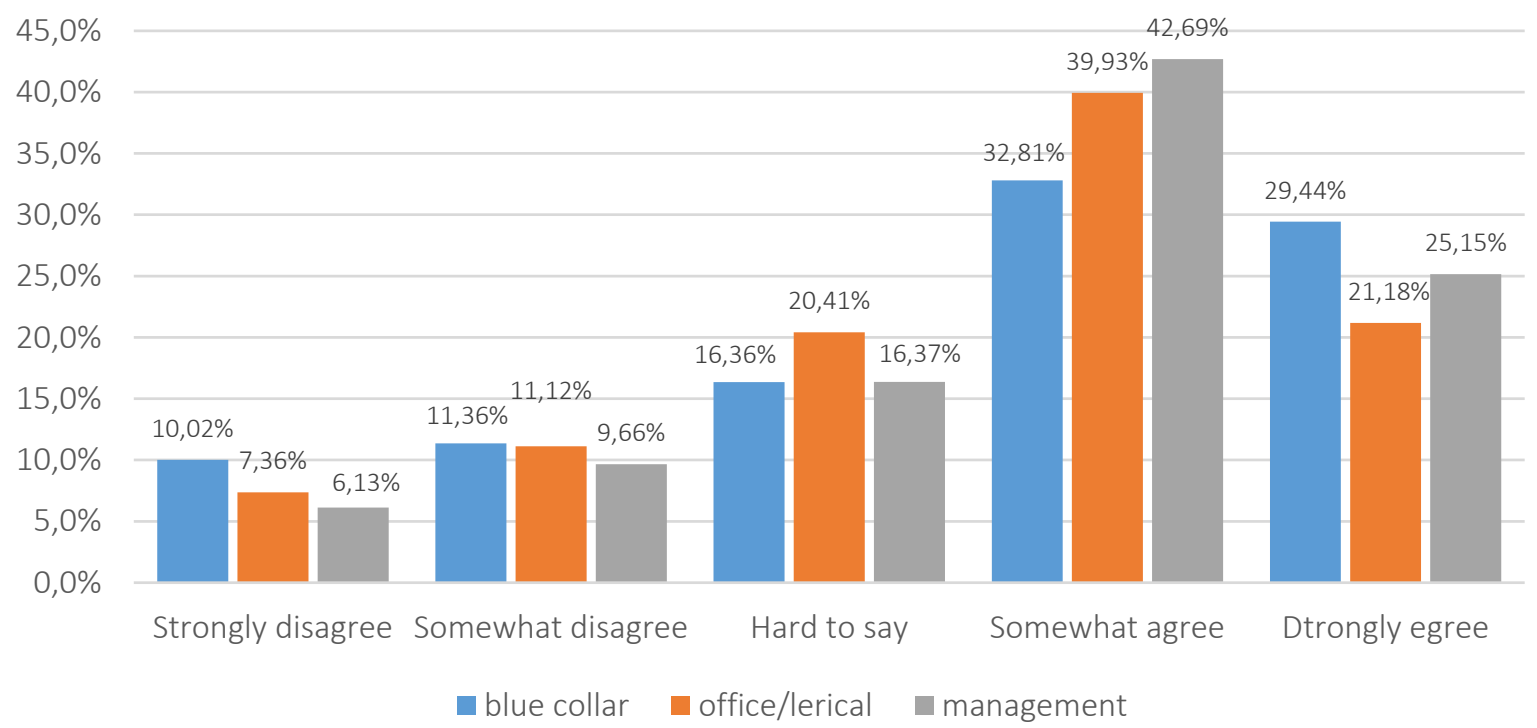

Figure 5. The quality of interpersonal relationships at work vs. a respondent's type of job

3 For the purposes of analyses and better depiction of the relationships, similar categories of education were combined, which resulted in three following categories: none and basic, vocational and secondary, higher. 


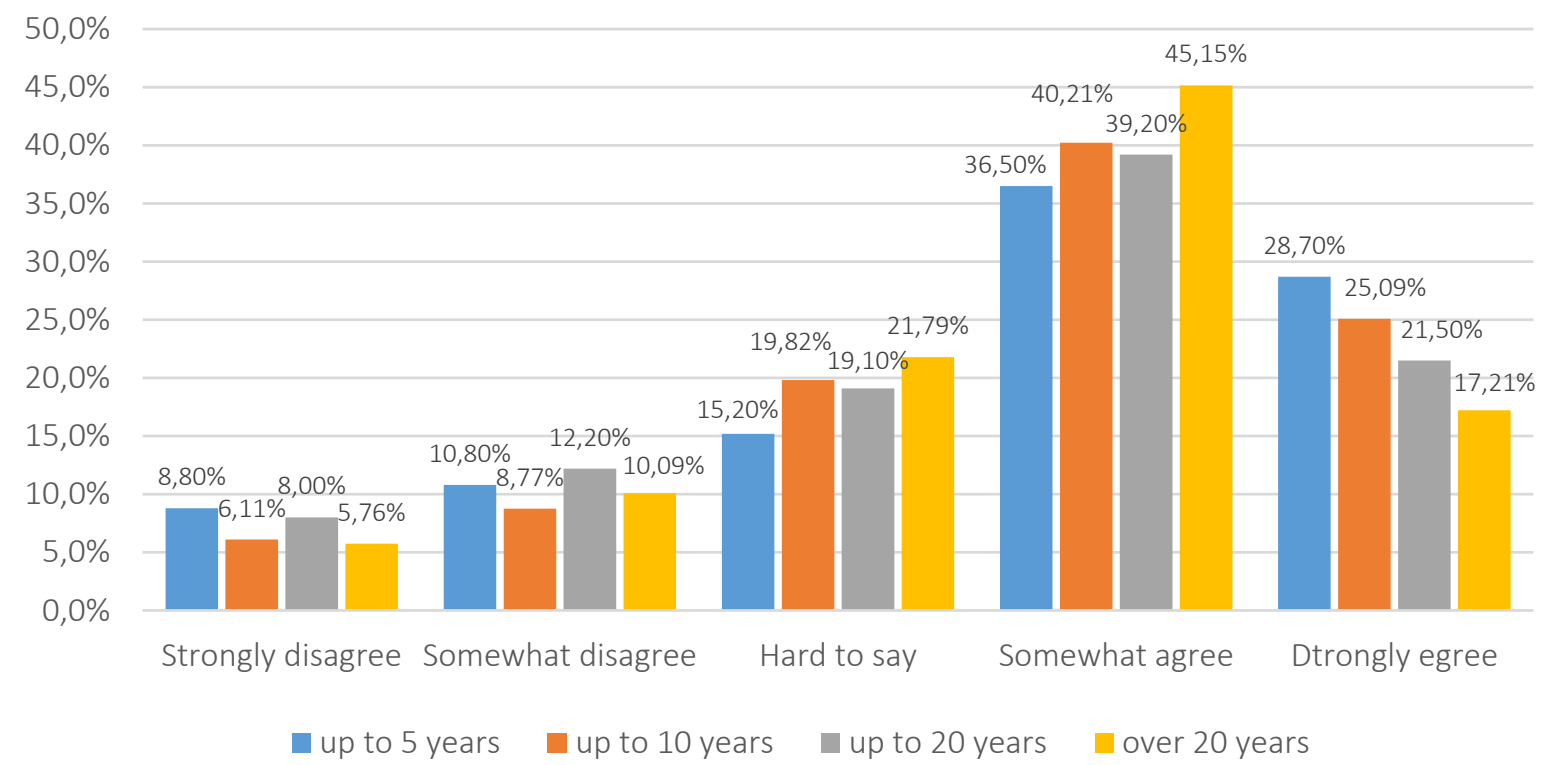

Figure 6. The quality of interpersonal relationships at work vs. a respondent's length of service

of work, it is hard to indicate clearly expressed trends in their assessment of the quality of interpersonal relationships at work. It is true that answers provided in particular groups are differentiated, but one cannot state it clearly that the quality increases or decreases depending on the length of service. For example, the group of workers with the shortest length of service tended to provide negative answers more frequently than in the case of the other groups, however, this group also tended to assess the relationships as positive more frequently (see Figure 6).

It should be noted that the described differences in assessing the quality of interpersonal relationships at work with respect to selected demographic var- iables (sex, age, education, type of job and length of service) proved statistically significant, which is manifested by values of Pearson's chi-square coefficients shown in Table 3.

Table 3. Pearson's chi-square coefficients for the relationship between the quality of interpersonal relationships at work and analyzed demographic variables

\begin{tabular}{l|c:c:c}
\hline \multicolumn{1}{c}{ QIRW vs... } & Chi-square & Df & Relevance \\
\hline Sex & 44.029 & 6 & $.000^{*}$ \\
\hline Age & 42.892 & 18 & $.000^{*}$ \\
\hline Education & 194.942 & 24 & $.000^{*}$ \\
\hline Type of job & 112.312 & 12 & $.000^{*}$ \\
\hline Length of service & 65.250 & 24 & $.000^{*}$ \\
\hline
\end{tabular}

Note: ${ }^{*}$ Chi-square statistics are relevant for $\alpha=0.05$.

\section{CONCLUSION}

The paper develops scientific research in the field of assessing the impact of employees' demographic characteristics on the quality of interpersonal relationships at work. The research aims to describe how selected characteristics of employees (sex, age, education, type of job, and length of service) influence the quality of interpersonal relationships.

The findings prove that the quality of interpersonal relationships at work is differentiated as follows: 1 ) by sex - men tend to assess the quality of relationships higher as compared to women); 2) by age - respondents belonging to younger groups tend to rate the quality of relationships higher as compared to older respondents); 3) by education - respondents with higher education tend to rate the quality of relationships higher as compared to less educated respondents, 4) by occupation - respondents holding managerial positions tended to assess the quality of the relationships higher as compared to respondents holding low-level positions; 5) by length of service (term of work) - indications were diversified in par- 
ticular groups selected with respect to the length of service; however, it was not possible to determine clearly expressed trends in assessing the quality of relationships depending on the length of service.

Based on the abovementioned, human resource managers (HRM) should systematically monitor the quality of interpersonal relationships between employees and actively shape this quality considering demographic characteristics of the staff. According to research results, special attention should be paid to the following categories of employees: women, older, less educated and blue-collar employees.

\section{LIMITATIONS AND FUTURE RESEARCH}

This study has some limitations such as:

- Certain target audience of respondents, which makes results not entirely objective.

- Limited anonymity caused, in particular, by the use of direct survey methods (a direct and auditory questionnaire). This could affect the reliability of the study, given its sensitive subject (the quality of relationships at work). Therefore, an online survey was additionally used (approx. 80\% of selected data).

- The quantitative nature of the study, which allowed only empirical confirmation of the influence of selected demographic variables on $\mathrm{QR}$.

Any future research should be enriched with qualitative methods (e.g. observations or focus group interviews) that will allow identifying the determinants of differences in the quality of relationships at work by analyzing demographic characteristics of employees. It is also worth trying to conduct a quantitative study on a representative sample, which will allow generalizing the results.

\section{AUTHOR CONTRIBUTIONS}

Conceptualization: Dawid Szostek.

Data curation: Dawid Szostek.

Formal analysis: Dawid Szostek.

Funding acquisition: Dawid Szostek.

Investigation: Dawid Szostek.

Methodology: Dawid Szostek.

Project administration: Dawid Szostek.

Resources: Dawid Szostek.

Software: Dawid Szostek.

Supervision: Dawid Szostek.

Validation: Dawid Szostek.

Visualization: Dawid Szostek.

Writing - original draft: Dawid Szostek.

Writing - review \& editing: Dawid Szostek.

\section{REFERENCES}

1. Atrek, B., Marcone, M. R., Gregori, G. L., Temperini, V., \& Moscatelli, L. (2014). Relationship Quality in Supply Chain Management: A Dyad Perspective. Ege Academic Review, 14(3), 371-381. Retrieved from https://www.researchgate. net/publication/304467684_Relationship_Quality_in_Supply_ Chain_Management_A_Dyad_Perspective
2. Belás, J., Bartoš, P., Ključnikov, A., \& Doležal, J. (2015). Risk perception differences between micro-, small and medium enterprises. Journal of 
International Studies, 8(3), 20-30. Retrieved from https://core.ac.uk/ download/pdf/43641138.pdf

3. Bowler, M., \& Brass, D. J. (2006). Relationship Correlates of Interpersonal Citizenship Behavior: A Social Network Perspective. Journal of Applied Psychology, 91(1), 70-82. https://doi.org/10.1037/00219010.91.1.70

4. Carmeli, A. (2009). Positive Work Relationships, Vitality, and Job Performance. In Ashkanasy, N., Zerbe, W. J., Härtel, C. E. J. (Eds.). Research on Emotions in Organizations: The Effect of Affect in Organizational Settings. Emerald Group, UK.

5. Carmeli, A., Brueller, D., \& Dutton, J. E. (2009). Learning Behaviours in the Workplace: The Role of High-quality Interpersonal Relationships and Psychological Safety. Systems Research and Behavioral Science, 26(1), 81-98. https://doi.org/10.1002/sres.932

6. Carmeli, A., \& Gittel, J. H. (2009). High-quality relationships, psychological safety, and learning from failures in work organizations. Journal of Organizational Behavior, 30(6), 709-729. https://doi.org/10.1002/ job.v30:610.1002/job.565

7. Gabarro, J. J. (1990). The Development of Working Relationships. In Intellectual Teamwork. Social and Technological Foundations Cooperative Work. In Galegher, J., Kraut, R.E., Egido, C. (Eds.), Intellectual teamwork: Social and technological foundations of cooperative work. Psychology Press, New York, USA; London, UK.

8. Gersick, C. J. G., Bartunek, J. M., \& Dutton, J. E. (2000). Learning from Academia: The Importance of Relationships in Professional Life. Academy of Management Journal, 43(6), 1026-1044. https:// doi.org/10.5465/1556333

9. Glińska-Neweś, A. (2017). Pozytywne relacje interpersonalne $w$ zarzadzaniu, Wydawnictwo UMK, Toruń.

10. Heaphy, E. D. (2009). Bodily Insights: Three Lenses on Positive
Organizational Relationships. In Dutton, J. E., Ragins, B. R. (Eds.), Exploring Positive Relationships at Work. Building a Theoretical and Research Foundation. Psychology Press, East Sussex/New York.

11. Hinde, R. A. (1997). Relationships: A Dialectical Perspective, Psychology Press, East Sussex, UK.

12. Jehn, K. A., Jonsen, K., \& Rispens, S. (2014). Relationships at Work: Intragroup Conflict and the Continuation of Task and Social Relationships in Workgroups. Current Topics in Management, 17, 1-22.

13. Jędrzejczak-Gas, J., \& Wyrwa, J. (2020). Determinants of job satisfaction in a transport company: a Polish case study. Equilibrium. Quarterly Journal of Economics and Economic Policy, 15(3), 565-593. https://doi. org/10.24136/eq.2020.025

14. Kot-Radojewska, M., \& Timenko, I. V. (2018). Employee loyalty to the organization in the context of the form of employment. Oeconomia Copernicana, 9(3), 511-527. https://doi.org/10.24136/ oc. 2018.026

15. Laschober, T. C., Allen, T. D., \& De TormesEby, L. T. (2012). Negative Nonwork Relational Exchanges and Links to Employees' Work Attitudes, Work Behaviors, and Well-being. In De TormesEby, L.T., Allen, T.D. (Eds.), Personal Relationships. The Effect on Employee Attitudes, Behavior, and Well-being. Taylor \& Francis Group, East Sussex, UK; New York, USA.

16. LePine, J. A., Methot, J. R., Crawford, E. R., \& Buckman, B. R. (2012). A Model of Positive Relationships in Team: The Role of Instrumental, Friendship, and Multiplex Social Network Ties. In Turner de TormesEby L., Allen T. D. (Eds.), Personal Relationships. The Effect on Employee Attitudes, Behavior, and Well-being. Taylor \& Francis Group, East Sussex/New York.

17. Lenart-Gansiniec, R., \& Sułkowski, Ł. (2020). Organizational learning and value creation in local governance: the mediating role of crowdsourcing. The Learning

Organization, 27(4), 321-335.

https://doi.org/10.1108/TLO-12-

2018-0213

18. Lušňáková, Z., Juríčková, Z., Šajbidorová, M., \& Lenčéšová, S. (2019). Succession as a sustainability factor of family business in Slovakia. Equilibrium. Quarterly Journal of Economics and Economic Policy, 14(3), 503520. https://doi.org/10.24136/ eq.2019.024

19. Mainela, T. (2007). Types and functions of social relationships in the organizing of an international joint venture. Industrial Marketing Management, 36(1), 87-98, https://doi.org/10.1016/j.indmarman.2005.08.003

20. McCauley, C. D. (2012). Reflection on Integration: SupervisorEmployee Relationships. In De TormesEby, L. T., Allen, T. D (Eds.), Personal Relationships. The Effect on Employee Attitudes, Behavior, and Well-being. Taylor \& Francis Group, East Sussex, UK; New York, USA.

21. McGinn, K. L. (2009). History, Structure, and Practices: San Pedro Longshoremen in the Face of Change. In Dutton, J. E., Ragins, B. R. (Eds.), Exploring Positive Relationships at Work. Building a Theoretical and Research Foundation. Psychology Press, East Sussex, UK; New York, USA.

22. O'Reilly, III, Ch. A., Caldwell, D. F., \& Barnett, W. P. (1989). Work Group Demography, Social Integration, and Turnover. Administrative Science Quarterly, 34(1), 21-37. https://doi. org/10.2307/2392984

23. Pisar, P., \& Bilkova, D. (2019). Controlling as a tool for SME management with an emphasis on innovations in the context of Industry 4.0. Equilibrium. Quarterly Journal of Economics and Economic Policy, 14(4), 763 785. https://doi.org/10.24136/ eq. 2019.035

24. Polyanska, A., Zapukhliak, I., \& Diuk, O. (2019). Culture of organization in conditions of changes as an ability of efficient transformations: the case of gas 
transportation companies in Ukraine. Oeconomia Copernicana, 10(3), 561-580. https://doi. org/10.24136/oc.2019.027

25. Przytuła, S., Rozkwitalska, M., Chmielecki, M., Sułkowski, Ł., \& Basinska, B. A. (2014). Cross-cultural interactions between expatriates and local managers in the light of Positive Organizational Behaviour. Social Sciences, 86(4), 14-24. Retrieved from https://www.researchgate. net/publication/276314986_CrossCultural_Interactions_between_ Expatriates_and_Local_Managers_in_the_Light_of_Positive_Organizational_Behaviour

26. Robak, E. (2017). Expectations of generation $\mathrm{Y}$ connected with shaping the work-life balance. The case of Poland. Oeconomia Copernicana, 8(4), 569-584. https://doi.org/10.24136/ oc.v8i4.35

27. Rzeczpospolita, Lista $500-E d y$ cja 2016. Retrieved from https:// sklep.rp.pl/produkt/lista_500 edycja_2015.php (24.02.2018).

28. Šafránková, J. M., \& Šikýřr, M. (2018). Responsibilities and competencies in personnel management at Czech schools. Oeconomia Copernicana, 9(3), 529-543. https://doi.org/10.24136/ oc. 2018.027

29. Sherony, K. M., \& Green, S. G. (2002). Coworker Exchange: Relationships between Coworkers,
Leader-Member Exchange, and Work Attitudes. Journal of Applied Psychology, 87(3), 542-548.

https://doi.org/10.1037//00219010.87.3.542

30. Storbacka, K.,Strandvik, T., \& Grönroos, C. (1994). Managing Customer Relationships for Profit: The Dynamics of Relationship Quality. International Journal of Service Industry Management, 5(5), 21-38. https://doi. org $/ 10.1108 / 09564239410074358$

31. Szostek, D. (2019). Kontrproduktywne zachowania organizacyjne $w$ kontekście jakości relacji interpersonalnych $w$ zespołach pracowniczych. Wydawnictwo Naukowe UMK, Toruń.

32. Szostek, D., \& Glińska-Neweś, A. (2017). Identyfikacja wymiarów jakości relacji interpersonalnych w organizacji. Organizacja i Kierowanie, 3, 11-24. Retrieved from http://yadda.icm.edu.pl/yadda/ element/bwmeta1.element.ekonelement-000171493116

33. Sułkowski, Ł., Przytuła, S., \& Migdał, A. M. (2020). Skilled Ukrainian migrants in the Polish emerging economy: implications for knowledge management. European Journal of International Management, 14(5), 796816. Retrieved from https:// www.researchgate.net/publication/345748943_Skilled_Ukrainian_migrants_in_the_Polish_ emerging_economy_implications_ for_knowledge_management
34. Tepper, B. J., \& Almeda, M. (2012). Negative Exchanges with Supervisors". In De TormesEby, L.T., Allen, T.D. (Eds.). Personal Relationships. The Effect on Employee Attitudes, Behavior, and Well-Being. Taylor \& Francis Group, East Sussex, UK; New York, USA.

35. Tschan, F., Semmer, N., \& Inversin, L. (2004). Work Related and "Private" Social Interactions at Work. Social Indicators Research, 67(1-2), 145-182. Retrieved from https://link. springer.com/article/10.1023/ B:SOCI.0000007338.60393.bf

36. Vasilyeva, T., Lyeonov, S., Adamičková, I., \& Bagmet, K. (2018). Institutional Quality of Social Sector: the Essence and Measurements. Economics and Sociology, 11(2), 248-262. https://doi.org/10.14254/2071789X.2018/11-2/17

37. Vveinhardt, J., \& Gulbovaite, E. (2018). Reliability of methodological and psychometric characteristics of the questionnaire of congruence of personal and organizational values. Oeconomia Copernicana, 9(3), 545-571. https://doi. org/10.24136/oc.2018.028

38. Wprost. Ranking 200 Największych Polskich Firm 2017. Retrieved from http://rankingi.wprost. pl/200-najwiekszych-firm\#pelnalista (10.09.2017). 


\section{APPENDIX}

The scale for measuring the quality of interpersonal relationships at work (Quality of Interpersonal Relationships in the Team Scale; QIRT-S)

Source: Szostek (2019, pp. 244-247)

To what extent, in your opinion, do the below statements apply to your work team? (please consider each of the below)

\begin{tabular}{l|c|c|c|c} 
Strongly & $\begin{array}{c}\text { Somewhat } \\
\text { disagree }\end{array}$ & $\begin{array}{c}\text { Hard to } \\
\text { say }\end{array}$ & $\begin{array}{c}\text { Somewhat } \\
\text { agree }\end{array}$ & $\begin{array}{c}\text { Strongly } \\
\text { agree }\end{array}$ \\
\hline
\end{tabular}

\footnotetext{
1. In the team, we talk about private matters

2. In the team, we know a lot about each other

3. In the team, we can predict each other's behavior and reactions

4. In the team, we respond to each other's needs

5. We have direct contact with each other in the team

6 . In the team, we are not afraid to voice opinions critical of the company
}

7. In the team, we're not afraid to say difficult things to each other

8. We speak honestly with each other in the team

9. We are not afraid to show negative emotions in the team

10. In the team, we show each other positive emotions

11. In the team, we help each other solve private problems

12. We joke with each other in the team

13. We like each other in the team

14. The team has social contact after work (e.g. we go to the cinema, the pub)

15. In the team, we show interest in each other's private matters

16. In the team, we share knowledge that is useful in private life

17. In the team, we can talk to our supervisor about everything

18. Our team's supervisor has a "human approach"

19. There is freedom of discussion within the team

20. In the team, the supervisor assigns us clear responsibilities

21. In the team, the supervisor treats us all fairly

22 . In the team, supervisors have social contact with subordinates

23. In the team, supervisors show an interest in employees' private matters

24. In the team, we effectively carry out our duties

25. In the team, we share the knowledge needed to accomplish tasks

26. We come to work happily

27. In the team, we help each other solve work-related problems

28. In the team, supervisors communicate all information (both good and bad) to subordinates

29. We are happy in the team

30. We work together in the team

31. We are loyal to each other in the team

32. We stick together in the team

33. We trust each other in the team

34. In the team6 we are good at overcoming internal conflicts and tensions

35. There is a good atmosphere in the team

36. There is no jealousy within the team

37. Within the team, we are discreet with one another on issues that are important to us

38. We treat each other well in the team

39. The company wants team relations to be positive

40. The company promotes teamwork

41. The company conducts regular consultations / meetings with employees/employee opinion surveys

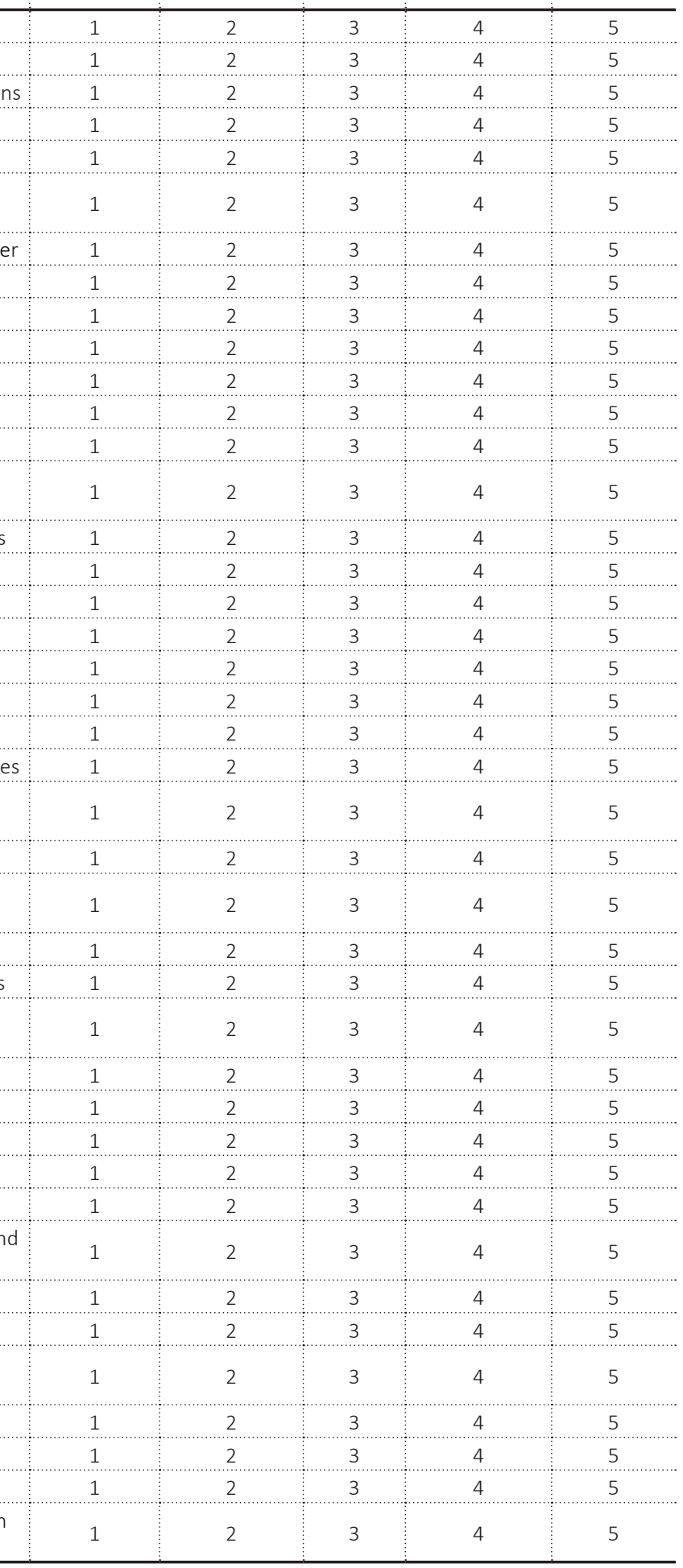




\begin{tabular}{|c|c|c|c|c|c|}
\hline $\begin{array}{l}\text { To what extent, in your opinion, do the below } \\
\text { statements apply to your work team? } \\
\text { (please consider each of the below) }\end{array}$ & $\begin{array}{l}\text { Strongly } \\
\text { disagree }\end{array}$ & $\begin{array}{l}\text { Somewhat } \\
\text { disagree }\end{array}$ & $\begin{array}{l}\text { Hard to } \\
\text { say }\end{array}$ & $\begin{array}{l}\text { Somewhat } \\
\text { agree }\end{array}$ & $\begin{array}{l}\text { Strongly } \\
\text { agree }\end{array}$ \\
\hline $\begin{array}{l}\text { 42. The company considers existing relationships when selecting } \\
\text { new employees for the team }\end{array}$ & 1 & 2 & 3 & 4 & 5 \\
\hline $\begin{array}{l}\text { 43. The company cares that the workplace is attractive and well } \\
\text { equipped }\end{array}$ & 1 & 2 & 3 & 4 & 5 \\
\hline $\begin{array}{l}\text { 44. There is a person in the team who takes care of the positive } \\
\text { atmosphere }\end{array}$ & 1 & 2 & 3 & 4 & 5 \\
\hline 45. Communication is effective in the team & 1 & 2 & 3 & 4 & 5 \\
\hline 46. We are not attached to a hierarchy or to formality in the team & 1 & 2 & 3 & 4 & 5 \\
\hline $\begin{array}{l}\text { 47. In the team, we are not afraid to ask each other questions or } \\
\text { for help in work matters }\end{array}$ & 1 & 2 & 3 & 4 & 5 \\
\hline $\begin{array}{l}\text { 48. In the team, we are not afraid to ask each other questions or } \\
\text { for help in private matters }\end{array}$ & 1 & 2 & 3 & 4 & 5 \\
\hline 49. The team eats meals, drinks coffee/tea, etc. together & 1 & 2 & 3 & 4 & 5 \\
\hline 50. In the team, we are able to listen to each other & 1 & 2 & 3 & 4 & 5 \\
\hline 51. We understand each other well in the team & 1 & 2 & 3 & 4 & 5 \\
\hline 52. We are involved in how the team functions & 1 & 2 & 3 & 4 & 5 \\
\hline 53. Being in the team gives us positive energy & 1 & 2 & 3 & 4 & 5 \\
\hline 54. In the team, we are empathetic and polite to one other & 1 & 2 & 3 & 4 & 5 \\
\hline 55. In the team, we are not afraid to admit to mistakes & 1 & 2 & 3 & 4 & 5 \\
\hline $\begin{array}{l}\text { 56. In the team, we celebrate important events together (e.g., } \\
\text { birthdays, saint days, anniversaries, successes) }\end{array}$ & 1 & 2 & 3 & 4 & 5 \\
\hline 57. In the team, we talk about work-related issues & 1 & 2 & 3 & 4 & 5 \\
\hline 58. In the team, we share ideas on how to improve tasks & 1 & 2 & 3 & 4 & 5 \\
\hline
\end{tabular}

Relationship quality categories and their related statements:

- organizational atmosphere: $8,12,19,24-27,29-38,44,45,47,50-55,57,58$

- interpersonal bonds: 1-7, 9-11, 13-16, 48, 49, 56

- methods of building of interpersonal relationships: $39-43$

- distance resulting from a management style: $17,18,20-23,28,46$ 